PAEDAGOGIA ChristianA

I /23(2009) - ISSN 1505-6872

Danuta Wajsprych ${ }^{*}$

Olsztyn

\title{
Wychowanie chrześcijańskie w świetle literatury i dokumentów Kościoła u progu trzeciego tysiąclecia - perspektywy rozwojowe
}

Rola pedagogii chrześcijańskiej w kształtowaniu tożsamości człowieka jako jednostki we wspólnocie życia społecznego nie podlega już dzisiaj szerszym dyskusjom. Wydaje się bowiem ona niezbędna nie tylko ze względu na przeszłość $i$ tradycję, ale przede wszystkim ze względu na teraźniejszość i przyszłość. Człowiek w dobie technologii informacyjnej, stale dokonujących się zmian cywilizacyjnych, niosących ze sobą konieczność rozwiązywania problemów natury egzystencjalnej, potrzebuje trwałych i stałych odniesień, stałych wartości, które umożliwią mu pełny rozwój osobowy. Na płaszczyźnie tej istotną rolę odgrywać może chrześcijańska koncepcja wychowania, w centrum której stoi człowiek jako osoba (świadomy i wolny podmiot) oraz jego integralny rozwój.

Podstawą do namysłu nad wychowaniem chrześcijańskim jest potrzeba sensu w znaczeniu ogólnym, a także poczucie sensu życia, którego dzisiaj młodzi ludzie pilnie poszukują. Od tego bowiem zależy, jaki kierunek nadadzą własnemu życiu. Odpowiedzi na pytania formułowane bardziej szczegółowo, ale i zarazem fundamentalne: o to, kim ma być człowiek XXI wieku, próbują obecnie udzielić w szczególności filozofia i teologia, ale także pedagogika, siłą rzeczy ukierunkowana najbardziej praktycznie.

Edukacja chrześcijańska nie zamierza poprzestać na tym, co uczyniono w przeszłości, co stanowi jej źródła i tradycję. Przepowiadanie religijne z natury swojej jest bowiem głoszeniem orędzia zbawienia człowiekowi żyjącemu w ciągle zmieniających się warunkach społeczno-kulturowych. Dlatego wychowanie

* Dr Danuta Wajsprych, adiunkt w Zakładzie Filozofii i Socjologii Edukacji Uniwersytetu Warmińsko-Mazurskiego w Olsztynie. 
religijne, chcąc właściwie wykonywać powierzoną mu misję, musi podlegać procesowi odnowy i rozwoju, a jego charakterystyczną cechą winna być wrażliwość na przemiany zachodzące $\mathrm{w}$ świecie i w Kościele oraz dążenie do nieustannej konfrontacji z rzeczywistością, w której ma oddziaływać ${ }^{\text {. }}$

Edukacja chrześcijańska, aby być skuteczna, musi odczytywać Ewangelię na nowo i wciąż na nowo ją głosić. Jan Paweł II, zajmując się kwestią jej odnowy, stwierdza, że: „podobnie jak i sam Kościół, zdąża ku lepszej przyszłości, która będzie wymagać aktywnej współpracy wszystkich osób zainteresowanych oraz uważnej otwartości wobec postępu ludzkiego społeczeństwa, tak i edukacja religijna musi sprostać temu wymaganiu"2. Potrzebę ciagłego otwarcia nauczania i wychowania chrześcijańskiego na nową rzeczywistość oraz jej perspektywicznego ukierunkowania zauważali również inni jego teoretycy, twierdząc, iż „edukacja ta, jeżeli ma być aktualna, znacząca i rozwijająca wiarę współczesnego człowieka, to należy ją ustawić przyszłościowo. Przyszłość bowiem jest najbardziej dynamiczną teraźniejszością"3.

Tak więc edukacja religijna, poszukując swego miejsca w przyszłości, chcąc pozostać wierną Bogu i człowiekowi, powinna uwzględniać kontekst społeczno-kulturowy, w którym żyją uczniowie oraz w tym kontekście czynić aktualnym Boże objawienie. Dlatego intencją niniejszego artykułu jest przedstawienie szans i możliwości edukacji chrześcijańskiej w perspektywie trzeciego tysiąclecia. Głównym natomiast celem jest próba odpowiedzi na pytanie, dlaczego warto a nawet trzeba czerpać w wychowaniu z inspiracji chrześcijańskiej.

\section{Kontekst społeczno-kulturowy współczesnego wychowania}

Ważnym aspektem obecnego wychowania jest bez wątpienia jego współczesny kontekst kulturowo-społeczny. Szczególnie w obecnej dobie młody człowiek poddany jest bardzo różnorodnym wpływom, a osoby i instytucje tradycyjnie zajmujące się wychowaniem, jak rodzice, nauczyciele, szkoła, a także Kościół, niejednokrotnie ustępują pola podmiotom nowym, w wielu przypadkach po prostu sprawniejszym z punktu widzenia zasad nowoczesnej organizacji i zarządzania, umiejętnie stosującym reguły różnych socjotechnik. Sytuacja taka stanowi z jednej strony zagrożenie, z drugiej zaś wyzwanie, wymuszając niejako wyciagnięcie odpowiednich wniosków i dokonanie koniecznych zmian. Uwaga ta dotyczy bez wątpienia również Kościoła katolickiego, a w jego ramach pedagogiki chrześcijańskiej.

We współczesnym świecie obserwujemy bardzo szybkie tempo przemian. Ukształtowane nowoczesne społeczeństwo jest społeczeństwem pluralistycznym. Pluralizm obserwowany w dzisiejszym świecie polega na wielości, zróżnicowa-

\footnotetext{
${ }^{1}$ Wnioski Międzynarodowego Kongresu Katechetycznego, „Katecheta” 1 (1972), s. 6-7.

2 Jan Paweł II, Wierze w Boga Ojca Stworzyciela, Città del Vaticano 1987, s. 26.

${ }^{3}$ M. Majewski, Katecheza a ewangelizacja i nowa ewangelizacja, Kraków 1995, s. 10.
} 
niu i konkurencji, występuje w ludzkiej świadomości oraz znajduje wsparcie w stosunkach społecznych. „Odznacza się on nie tylko wielością i różnorodnością kultur, ideologii i religii, ale także konkurencją i współzawodnictwem między autonomicznymi podmiotami życia społecznego w obszarze podstawowych celów i wartości. Konkurencja i współzawodnictwo występuje tam, gdzie nie ma konsensusu, homogeniczności i monopolu światopoglądowego"4. Konkurencja ta posiada szczególnie ważną pozycję w sytuacji pluralizmu kulturowego oraz jego konsekwencji - pluralizmu społecznego.

Pluralizm kulturowy stanowi sytuację, w której mamy do czynienia ze współzawodnictwem dotyczącym światopoglądów, filozofii życia i systemów znaczeń oraz pozyskiwaniem dla nich tzw. klientów na rynku światopoglądowym. Często w sytuacji pluralizmu kulturowego osoba ludzka kieruje się ku tym wartościom, które w subiektywnej ocenie są dla niej najważniejsze. W wielu przypadkach są to wartości będące „W zasięgu ręki” i one zostają podniesione do rangi wartości absolutnych5.

Pluralizm społeczny jest z kolei związany z ,istnieniem i funkcjonowaniem różnorodnych, autonomicznych podmiotów konkurujących w urzeczywistnianiu własnych celów. Określa on strukturę społeczeństwa, w którym liczne i mniej lub więcej niezależne od siebie, zorganizowane według kryteriów, norm i wartości oraz będące we wzajemnej konkurencji grupy i instytucje walczą o wpływy społeczne i polityczne" ${ }^{\text {" }}$. Ważną rolę we właściwym funkcjonowaniu pluralizmu społecznego odgrywa prawo, które stoi na straży dobra wspólnego. Prawo bowiem zabezpiecza istniejącą podmiotowość społeczeństwa i jego celem jest tworzenie odpowiedniej przestrzeni dla istnienia, działania i autonomii podmiotów społecznych. Zadaniem prawa jest także uruchamianie szerokiej gamy społeczności pośrednich, które obok rodziny spełniałyby istotną rolę w tworzeniu solidarnego społeczeństwa. „Pluralizm społeczny dopiero w harmonii z ową solidarnością, dobrem wspólnym i prawem może być odpowiednim środowiskiem rozwojowym dla osoby ludzkiej"7.

Współczesny pluralizm społeczno-kulturowy kształtuje dla współczesnego człowieka specyficzne środowisko życia. Oferuje on człowiekowi duże możliwości wyboru we wszystkich dziedzinach życia. Każda bowiem grupa społeczna ma możliwość rozpowszechniania swoich własnych wartości i ideałów. Człowiek w społeczeństwie pluralistycznym przynależy do wielu różnorodnych grup społecznych, które nierzadko proponują mu sprzeczne systemy wartości, przez co człowiek często zmienia stosunek do siebie, ludzi, świata, wartości i religii ${ }^{8}$.

${ }^{4}$ R. Kamiński, Duszpasterstwo w społeczeństwie pluralistycznym, Lublin 1997, s. 20.

${ }^{5}$ B. Drożdż, Wychowawcza funkcja w społeczeństwie pluralistycznym, Legnica 1997, s. 18.

${ }^{6}$ R. Kamiński, dz. cyt., s. 23.

${ }^{7}$ Tamże, s. 24.

${ }^{8}$ B. Drożdż, dz. cyt., s. 39-40; R. Kamiński, dz. cyt., s. 29; M. Majewski, Aktualne wyzwania katechetyczne, Kraków 1997, s. 10-11. 
Szybkie tempo przemian we współczesnym świecie, wraz z pluralizmem społeczno-kulturowym, niesie ze sobą zarówno pozytywne, jak i negatywne wartości. Przemiany w świecie i społeczeństwie otworzyły przed człowiekiem nowe perspektywy. Z obywatela państwa stał się Europejczykiem i obywatelem globu, a w swych planach - obywatelem wszechświata. Świat stał się dla niego bardziej otwarty. Niewątpliwy wpływ wywarła na to chęć człowieka do panowania nad światem ${ }^{9}$. Odwieczny ludzki wysiłek, by uczynić sobie ziemię poddaną, obficie zaowocował szczególnie w ostatnich latach. Wyraża się to w postępie naukowo-technicznym, w wynalazkach, o których marzyły poprzednie pokolenia. Jak zauważa A. Exeler, „w obrębie nauk przyrodniczych zrobiono o wiele więcej odkryć i wynalazków niż we wszystkich tysiącleciach minionej historii ludzkości" ${ }^{10}$. To wszystko wpływa na świadomość człowieka, który coraz bardziej zaczyna traktować świat jako środowisko sprzyjające jego rozwojowi.

\section{Dokumenty Kościoła wobec wyzwań współczesności}

Wiele pozytywnych wartości zmian zachodzących we współczesnym świecie odnotowują dokumenty Kościoła. Zwracają one uwagę, iż człowiek jeszcze nigdy nie doszedł do takiej wiedzy o świecie i do takiego jego opanowania, jak obecnie. Dzięki postępowi nauki, techniki i kultury człowiek rozwija się i wzbogaca duchowo oraz bardziej świadomie czuje się odpowiedzialny za świat. Na fundamencie odkrywanej autonomii duchowej rozwija się nowy humanizm. Dzięki środkom masowej informacji człowiek doświadcza, że jest członkiem jednej wielkiej rodziny ludzkiej i w ten sposób tworzy się zrąb ogólnoludzkiej cywilizacji powszechnej. W związku z tym wzrasta konieczność współpracy międzynarodowej w różnych dziedzinach życia. Współpraca - jak czytamy w Konstytucji duszpasterskiej o Kościele - zmusza do porozumiewania się ludzi ponad przekonaniami religijnymi czy światopoglądowymi ${ }^{11}$. Obserwujemy także wzrost poczucia godności osoby ludzkiej i przysługujących jej praw. Zdaniem Jana Pawła II, dziś ,„coraz bardziej umacnia się poczucie osobistej godności każdej ludzkiej istoty. Dobroczynny prąd przenika, ogarnia wszystkie ludy świata, które coraz lepiej uświadamiają sobie godność człowieka, a więc nie „rzeczy” lub „przedmiotu”, którym można się posługiwać” ${ }^{2}$.

Obok pozytywnych wartości, współczesny świat niesie także wiele zagrożeń. „Społeczeństwo pluralistyczne stara się narzucić człowiekowi wiele pozor-

${ }^{9}$ Gaudium et spes. Konstytucja duszpasterska o Kościele w świecie wspótczesnym, Watykan 1965, s. 10.

${ }^{10}$ Por. T. Panuś, Katecheza dorosłych w świetle dokumentów Synodu Archidiecezji Krakowskiej z lat 1972-1979, Lublin 1992 (mps KUL), s. 10.

${ }^{11}$ Gaudium et spes, s. 4, 7, 25, 26. Por. też A. Szafrański, Kairologia. Zarys nauki o świecie wspótczesnym, Lublin 1990, s. 37-45.

${ }^{12}$ Gravissimum educationis. Deklaracja o wychowaniu chrześsijańskim, Watykan 1965, s. 5. 
nych imperatywów, uzasadnianych prawem rozwoju i postępu"13. Według Jana Pawła II, w społeczeństwie, które utrzymuje, iż nie istnieją prawdy uniwersalne, nie ma też wartości absolutnych, natomiast dobro i zło nie mają żadnego znaczenia. Dobro bowiem zaczyna oznaczać to, co w danej chwili jest użyteczne i sprawia przyjemność, zaś złem jest to wszystko, co stoi na przeszkodzie w zaspokajaniu subiektywnych potrzeb. I w ten sposób każdy może tworzyć swój własny system wartości. W społeczeństwie tym rodzi się również powątpiewanie, że „tylko w prawdzie można znaleźć zbawienie. Poddaje się w wątpliwość zbawczą moc prawdy, pozostawiając samej wolności, oderwanej od wszelkich obiektywnych uwarunkowań, zadanie samodzielnego decydowania o tym, co dobre, a co złe"14.

Zjawiskiem niekorzystnym, towarzyszącym pluralizmowi społeczno-kulturowemu, jest sekularyzacja. Stanowi ona przeciwieństwo sakralizacji i „oznacza proces stopniowego wyzwalania się różnych dziedzin życia spod wpływów religijnych instytucji i systemów znaczeń" ${ }^{15}$. Sekularyzacja uobecnia się poprzez hedonizm, pragmatyzm, pogoń za sukcesem, negację norm etycznych. Jest ona częstą przyczyną relatywizmu moralnego i obojętności religijnej, objawiającej się tym, że wielu ludzi usuwa Boga z ich egzystencjalnego horyzontu i żyje tak, jakby Bóg nie istniał ${ }^{16}$. Sekularyzacja, zdaniem Jana Pawła II, prowadzi do ateizmu ${ }^{17}$. W Liście apostolskim Tertio millennio adveniente Papież charakteryzuje sytuację współczesnego człowieka następująco:

wielu współczesnych ludzi żyje dziś tak, jak gdyby Bóg nie istniał, albo zadowala się mglistą religijnością, niezdolną sprostać problemowi prawdy, ani obowiązkowi zachowania spójności między życiem i wiarą? Należy do tego dodać także powszechną utratę poczucia transcendentnego sensu ludzkiej egzystencji oraz zagubienie na polu etyki, obejmujące nawet tak fundamentalne wartości, jak szacunek dla życia i rodziny ${ }^{18}$.

Subiektywizm religijny, jaki niesie z sobą społeczeństwo pluralistyczne, osłabia także przynależność do Kościoła. Ekspansja ruchów religijnych, sekt, stowarzyszeń i organizacji o charakterze światopoglądowym, ideologicznym wpływa na to, iż wielu ludzi odchodzi od Kościoła ${ }^{19}$.

${ }^{13}$ R. Kamiński, dz. cyt., s. 25.

${ }^{14}$ Gravissimum educationis, s. 5; por. także R. Kamiński, dz. cyt., s. 28.

15 Tamże, s. 17.

${ }^{16}$ B. Drożdż, dz. cyt., s. 45. Por. A. Lewek, Nowa Ewangelizacja w duchu Soboru Watykańskiego II, Katowice 1995, s. 143-157.

${ }^{17}$ Por. tamże, s. 157-177.

${ }^{18}$ Tertio millennio adveniente. List apostolski Jana Pawła II do Biskupów, Duchowieństwa Wiernych w zwiqzku z przygotowaniem Jubileuszu Roku 2000, Watykan 1994, s. 36.

${ }^{19}$ Por. M. Rusecki, Dlaczego sekty sq niebezpieczne, w: tenże (red.), Problemy wspótczesnego Kościoła, Lublin 1996, s. 203-223. 
Współczesny człowiek, żyjący w świecie pluralistycznym, często gubi się wśród panującego chaosu religijnego, społecznego, kulturowego i politycznego. Nie dostrzega przed sobą prostej i jasnej drogi wytyczającej cel jego ludzkiej egzystencji. Pluralizm nie stanowi jednak zjawiska, które należy eliminować, ale jest faktem, który należy uwzględniać. „Kościół, który jest znawcą spraw ludzkich, widząc zagrożenia i wewnętrzną walkę, będącą udziałem człowieka żyjącego w społeczeństwie pluralistycznym, powinien poprzez swoją obecność i duszpasterstwo roztoczyć troskę, w świetle której egzystencja człowieka w społeczeństwie pluralistycznym nabierze nowego blasku i nadziei"20. To zadanie staje także przed edukacją religijną, która nie tylko w ramach działalności duszpasterskiej Kościoła, ale i szkoły, podejmuje trud głoszenia orędzia zbawienia współczesnemu człowiekowi. Pomimo że uwarunkowania społecznokulturowe i religijno-moralne bardziej wskazują na niekorzystne ograniczenia, niż na perspektywy nauczania i wychowania religijnego, to jednak perspektywy tej edukacji należy widzieć nie tyle w kategoriach możliwości i popytu, a przede wszystkim potrzeby i konieczności. „Biorąc pod uwagę te ostatnie kategorie trzeba stwierdzić, że właściwie przedstawiona sytuacja stwarza szczególne perspektywy poważnie potraktowanej integralnej edukacji religijnej"21. Współczesność stanowi zatem wyzwanie dla tej edukacji, aby odnajdywała człowieka żyjącego w społeczeństwie pluralistycznym i pomagała mu w odkrywaniu Bożej rzeczywistości.

Odkrycie współczesnemu człowiekowi, często zagubionemu, zbawczego planu Boga wymaga nowego światła Ewangelii. Jan Paweł II od początku swego pontyfikatu podejmuje wezwanie nowej ewangelizacji. Pojęcie ,nowa ewangelizacja" zakłada ewangelizację już dokonaną, która domaga się reewangelizacji ${ }^{22}$. Antoni Lewek, analizując wypowiedzi Papieża oraz dokumenty katechetyczne Kościoła, wyprowadza następującą definicję nowej ewangelizacji:

Nowa ewangelizacja to odnowiona w duchu Vaticanum II i dostosowana do dzisiejszych uwarunkowań społeczno-kulturowych działalność ewangelizacyjna wszystkich chrześcijan, którzy czerpiąc ze źródeł Objawienia, dzięki pomocy Ducha Świętego, starają się z nowym zapałem i wszelkimi możliwymi sposobami przekazywać Ewangelię Jezusa Chrystusa o wielkiej miłości Boga do człowieka wszystkim ludziom, zwłaszcza swoim współbraciom zdechrystianizowanym, celem wzbudzenia i ukształtowania w nich dojrzałej wiary chrześcijańskiej jako fundamentu ich zbawienia, czyli zjednoczenia z Bogiem w Chrystusie i Jego Kościele ${ }^{23}$.

${ }^{20}$ R. Kamiński, dz. cyt., s. 26.

${ }^{21}$ Tamże, s. 26-27.

${ }^{22}$ W. Piwowarski, Katolicyzm polski jako religijność narodu, w: W. Zdaniewicz (red.), Religia i życie społeczne, Poznań-Warszawa 1983, s. 82.

${ }^{23}$ A. Lewek, Ku integralnej koncepcji nowej ewangelizacji, „Ateneum Kapłańskie” 515 (1995), s. 15. Por. R. Murawski, Katecheza - Ewangelizacja, „Katecheta” 23 (1985), s. 259-279. 
Ewangelizacja zatem oznacza zapoczątkowanie pierwszego lub całościowego otwarcia na Boga, trwały kontakt z Nim, uświadomienie właściwej hierarchii wartości oraz refleksję nad sensem życia. W tak rozumianą ewangelizację wpisuje się wizja integralnego rozwoju człowieka, gdyż istnieje również „ewangelizacja wychowania i wychowanie ewangelizacyjne"24.

Papież w wielu swoich wypowiedziach podkreśla wartość Ewangelii, jako rzeczywistości wprowadzającej w trzecie tysiąclecie chrześcijaństwa. W Orędziu na Światowy Dzień Misyjny wypowiada następujące słowa:

W perspektywie Jubileuszu odkupienia, który będziemy obchodzili w roku 2000 dostrzegam świt nowej ery misyjnej. Obok zjawisk negatywnych nie brak także w dzisiejszym świecie oznak, że ludzkość coraz bardziej i zdecydowanie opowiada się za ideałami Ewangelii. Są nimi na przykład odrzucenie przemocy i wojny; szacunek dla osoby ludzkiej i jej praw; pragnienie wolności, sprawiedliwości i braterstwa ${ }^{25}$.

Potrzebę nowej ewangelizacji Europy Jan Paweł II dostrzega w trzech aspektach:

1. Wierność Europy swojej tożsamości chrześcijańskiej. Europa jest kontynentem chrześcijańskim w swych korzeniach, dlatego nie można zrozumieć kultury europejskiej, nie odnosząc się wprost do chrześcijaństwa.

2. Wierność współczesnemu człowiekowi europejskiemu. W złożonym, pluralistycznym, zsekularyzowanym, a często nawet nihilistycznym społeczeństwie europejskim żyje człowiek, który mimo niepokoju i beznadziejności nosi w sobie głębokie pytanie o wartości religijne i sens życia.

3. Wierność misji powierzonej przez Chrystusa Kościołowi. Ta wierność powinna opierać się na:

a) przywróceniu Europie jej autentycznej tożsamości, w której nowa ewangelizacja powinna doprowadzić do tego, aby człowiek utożsamiał się egzystencjalnie i kulturowo ze swoimi korzeniami ewangelicznymi;

b) odzyskaniu jedności kultury i religii, gdzie zadaniem nowej ewangelizacji jest także tworzenie więzów komunii kościelnej i społecznej;

c) inkulturowaniu Ewangelii, co powinno zmierzać do utworzenia nowej syntezy Ewangelii i życia ${ }^{26}$.

Misją Kościoła, który przewodzi cywilizacji światowej, jest pokazanie, że można odważnie i autentycznie podejmować wezwania Ewangelii we współczesnych społeczeństwach, że wiara w Boga może być obecna w nowym stechnicyzowanym i złożonym świecie, że jest możliwe zintegrowanie techniki i czło-

${ }^{24}$ M. Majewski, dz. cyt., s. 26.

${ }^{25}$ Jan Paweł II, Orędzie na Światowy dzień Misyjny, „L'Osservatore Romano” 8-9 (1992), nr 13, s. 20.

${ }^{26}$ Por. J. Rodriguez, Nowa Ewangelizacja Europy w nauczaniu Jana Pawła II, w: Nowa Ewangelizacja, Kolekcja Communio, t. 8, Poznań 1993, s. 166-181. 
wieczeństwa. Nowa ewangelizacja powinna być skierowana do całych grup ludzkich, żyjących w różnych środowiskach i kulturach, aby swoim szerokim oddziaływaniem kształtowała dojrzałe wspólnoty kościelne ${ }^{27}$.

Wypowiedzi Jana Pawła II nacechowane są troską o człowieka, który zagubiony we współczesnych warunkach życia poszukuje drogi, pewności i prawdy. Troska ta dotyczy również potrzeby aktualizacji orędzia zbawienia, tak aby dokonała się harmonia wiary i życia.

Pluralizm społeczno-kulturowy oraz przemiany religijno-moralne maja miejsce również w Polsce. Nowa rzeczywistość społeczna, która ukształtowała się w Polsce w latach 80., jest nową rzeczywistością Kościoła - również edukacji religijnej. Kościół w Polsce przestał być postrzegany jako jedyna wiarygodna instytucja, ciesząca się szacunkiem i poważaniem. Dzisiaj bowiem różne idee i ideologie, a także różne religie wzmocniły swoją siłę oddziaływania, docierając do szerokich kręgów ludzi. Coraz częściej można zauważyć rozdźwięk między życiem a wiarą. Dodatkowym wyzwaniem dla polskiej edukacji religijnej był jej powrót do szkoły. Ta nowa sytuacja przyniosła z sobą wiele problemów, które stanowią wyzwania dla współczesnej integralnej koncepcji rozwoju religijnego ${ }^{28}$.

Religijna edukacja szkolna rodzi niebezpieczeństwo przeakcentowania wiedzy religijnej. Zadaniem jej nie jest jednak tylko przekaz tej wiedzy, ale powinna ona rozwijać świadomość religijną i kulturową dzieci i młodzieży szkolnej oraz pozytywne cechy charakteru, ducha wolności religijnej i braterstwa, solidarności międzyludzkiej, narodowej i ogólnoświatowej. Katechizacja w szkole winna stać się ważnym czynnikiem moralnej i cywilizacyjnej odnowy narodu ${ }^{29}$. Na potrzebę wkładu edukacji religijnej w umacnianie tożsamości kulturowej narodu wskazał list Episkopatu Polski:

musi być ona (edukacja religijna) także dostrzeżona jako dobro służące poczuciu narodowej i kulturowej tożsamości [...]. Nie da się zastąpić edukacji religijnej najlepszymi nawet przykładami i podręcznikami ukazującymi rolę chrześcijaństwa w naszych dziejach i naszej kulturze. Potrzeba dotknąć samego źródła. Trzeba przez poznanie Boga i tego, czego uczy objawienie, dostrzec, jak głęboko chrześcijaństwo zapuściło korzenie w ludzkich duszach tej ziemi. Z tych korzeni czerpano i czerpie się nadal twórcze inspiracje. One stanowią o swoistym etosie narodu, który ukształtował się w świetle Bożych zasad życia jednostkowego i zbiorowego ${ }^{30}$.

${ }_{27}^{27}$ J. Mariański, Kościót a wspótczesne problemy spoleczno-moralne, Lublin 1992, s. 238.

${ }^{28}$ Por. T. Miłek, Katecheza szkolna - nadzieje i obawy, „Katecheta” 2 (1995), s. 98-99; M. Majewski, Szkoła podmiotem uczenia religii i katechezy, w: M. Majewski (red.), Katecheza w szkole, Lublin 1992, s. 45-50.

${ }^{29}$ Z. Łyko, Stanowisko Kościołów niekatolickich w sprawie nauczania religii w szkole, w: J. Krakowski (red.), Nauczanie religii w szkole w państwie demokratycznym, Lublin 1991, s. 39. Por. M. Majewski, Szkoła podmiotem, s. 5-55.

${ }^{30}$ List Pasterski Episkopatu Polski w sprawie powrotu katechizacji do szkoty polskiej, „Miesięcznik Kościelny Archidiecezji Poznańskiej” 8 (1990), s. 297, cyt. za: M. Majewski, Szkoła podmiotem, s. 31. 
Z powyższego wypływają następujące wnioski dla nauczania i wychowania religijnego:

- zajmowanie się wielostronną interpretacją egzystencji ludzkiej;

- koncentrowanie uwagi na kształceniu refleksyjności, krytycyzmu i wyrobieniu pełnej orientacji dotyczącej świata i człowieka;

- pomaganie uczniom w odkrywaniu prawdy, że istnienie człowieka jest ściśle związane z życiem innych;

- w czasach religijnego pluralizmu przedstawienie różnych wyznań, wierzeń i postaw religijnych;

- podejmowanie wydarzeń z zakresu życia społecznego i kulturalnego oraz wskazywanie na ich związki z życiem religijnym;

- kształtowanie postawy otwartej, krytycznej i odpowiedzialnej w ramach całego Kościoła i poza nim ${ }^{31}$.

Postulaty dotyczące polskiej edukacji religijnej w warunkach szkolnych ściśle łączą się z przyszłością uczniów. Szczegółowe zadania stawiane przed współczesną edukacją wpływają na rozwój osoby ludzkiej i postawy chrześcijańskiej. Wykształcenie w uczniu świadomości chrześcijańskiej wymaga głębokiej refleksji, zaangażowania duszpasterskiego, doświadczeń życiowych, a zwłaszcza Bożego oświecenia, aby człowiek nie tylko uwierzył, przyjmując Ewangelię i naukę Kościoła, ale umiał w niej dostrzec sens i wartość dla swojego życia. Takim zadaniom, jakie stoją dziś przed nauczaniem i wychowaniem, może sprostać właśnie ewangelizacja wierna Bogu i człowiekowi ${ }^{32}$.

Analizując sytuację współczesnego świata, dostrzegamy chaos przeciwstawnych światopoglądów, religii, wartości i idei. Na takim gruncie rodzi się potrzeba ukazania całościowej wizji chrześcijańskiego życia, w którym w harmonijną całość łączą się prawda i wolność, modlitwa i czyn, refleksja i kontemplacja. Dziełem będącym przejawem odpowiedzialności za ewangelizację, łączącym wiarę i życie, jest Katechizm Kościoła Katolickiego opublikowany w 1992 roku. Katechizm jest darem skierowanym ku przyszłości, ku nowemu tysiącleciu. Jan Paweł II, wypowiadając się na temat roli Katechizmu Kościoła Katolickiego, stwierdził, że:

W dzisiejszym świecie, w którym niepokojące procesy sekularyzacji prowadzą często do ateizmu, a przejawem silniejszej tęsknoty za sacrum są różne formy subiektywizmu i mnożenia się wątpliwej wartości ruchów religijnych, dostrzegamy powszechną potrzebę oparcia na pewnych podstawach wyznania wiary oraz osobistego doświadczenia chrześcijańskiego życia. Tę potrzebę pragnie zaspokoić opublikowany niedawno katechizm, który ze względu na swą naturę tekstu naprawdę katechetycznego z pewnością przysłuży się dziełu nowej ewangelizacji, przedstawiając pełne orędzie Chrystusa, w niczym nie umniejszone ani nie zniekształcone ${ }^{33}$.

${ }^{31}$ Por. M. Majewski, Katecheza integralna w szkole, „Katecheta” 2 (1992), s. 65-72.

${ }^{32}$ Tenże, Aktualne wyzwania, s. 29.

${ }^{33}$ Jan Paweł II, Rola Katechizmu Kościoła Katolickiego w duszpasterstwie, Przemówienie 
Katechizm, przekazując całość depozytu wiary w konkretnych warunkach życiowych współczesnego człowieka, realizuje zasadę wierności Bogu i człowiekowi ${ }^{34}$.

W poszukiwaniu wytycznych dla współczesnej edukacji religijnej człowieka, szczególnie ważne wydają się być wskazania Jana Pawła II zawarte w cytowanym już liście apostolskim Tertio millennio adveniente. List ten wytycza szlak prowadzący Kościól, a z nim całą ludzkość, w trzecie tysiąclecie chrześcijaństwa. Papież prosi ,,chrześcijan postarzałych, zmęczonych i niekiedy zniechęconych, by stali się współczesnymi Chrystusowi i Jego Ewangelii; by odkryć w końcu siły i entuzjazm z czasów apostolskich" ${ }^{35}$. Ujmując chrystocentrycznie perspektywy przekazu orędzia zbawienia, Papież sięga do tego, co zawarł już w swojej encyklice Redemptor hominis: „Człowiek, który chce zrozumieć siebie do końca - nie wedle jakiś tylko doraźnych, częściowych, czasem powierzchownych, a nawet pozornych kryteriów - musi ze swoim niepokojem, niepewnościa, a także słabością i grzesznością, ze swoim życiem i śmiercią, przybliżyć się do Chrystusa. Musi niejako w Niego wejść z sobą samym, musi sobie przyswoić, zasymilować całą rzeczywistość Wcielenia i Odkupienia"36. Odkrycie na nowo edukacji religijnej jako nauczania o osobie Jezusa Chrystusa i o jego „Tajemnicy zbawienia" 37 , stanowi fundament orędzia zbawienia skierowanego ku przyszłości i powinno ożywiać wiarę oraz wzmocnić świadectwo chrześcijan ${ }^{38}$.

Tertio millennio adveniente opisuje drogę, którą różne wspólnoty eklezjalne powinny podjąć w celu ożywienia wiary i dania o niej konkretnego świadectwa ${ }^{39}$. Pierwszym krokiem na tej drodze ma być odkrycie na nowo rozumowych podstaw wiary. Konieczne jest to, aby człowiek żyjący współcześnie potrafił odpowiedzieć na pytanie: „«dlaczego wierzę?», bez wahania i dwuznaczności, ale mając pewność dokonanego wyboru, który daje sens jego istnieniu. Pomijanie w ostatnich dziesięcioleciach rozumowych podstaw wiary powoduje poślizg ku formom niejasnym i dwuznacznym wiary, często błędnym" ${ }^{\prime 0}$.

Drugim zadaniem stawianym przez Jana Pawła II w Liście Apostolskim jest przemyślenie na nowo centralnego miejsca Jezusa Chrystusa. Papież podkreśla

z 29.04.1993 r., w: Wprowadzenie do Katechizmu Kościoła Katolickiego, Warszawa 1994, s. 135$-136$.

${ }^{34}$ Por. A. Canizares, O nowym Katechizmie Kościoła Katolickiego, „Communio” 4 (1994), s. $48-56$.

${ }^{35}$ R. Etchegaray, Wprowadzenie. List Apostolski Tertio millennio adveniente, w: Tertio millennio adveniente. Komentarz teologiczno-pastoralny w opracowaniu Rady Prezydium Wielkiego Jubileuszu Roku 2000, Sandomierz 1995, s. 7.

${ }^{36}$ Redemptor hominis. Encyklika papieża Jana Pawła II o Odkupicielu człowieka, Watykan 1979, s. 10.

${ }^{37}$ Tertio millennio adveniente, s. 42.

${ }^{38}$ R. Etchegaray, dz. cyt., s. 8-9.

${ }^{39}$ R. Fisichella, Rok święty znakiem wiary, która nie męczy się nigdy szukaniem, w: Tertio millennio adveniente. Komentarz, s. 169.

${ }^{40}$ Tamże, s. 170. 
wartość faktu Wcielenia dla wiary chrześcijańskiej ${ }^{41}$. Wiara chrześcijańska nie bazuje na jakiejś idei, ale na osobie Jezusa Chrystusa i w nim znajduje pełne rozwiązanie. Centralność osoby Chrystusa stanowi wymiar najbardziej charakteryzujący wiarę chrześcijańską, w której Jezus Chrystus objawia Ojca i Jego tajemnice życia trynitarnego, ostatecznego celu drogi wiary oraz ostatecznej chwały, która uobecnia się w liturgii ${ }^{42}$.

Odkrycie centralnego miejsca Chrystusa skłania nas do Jego charakterystyki, jako „Pedagoga i Ewangelizatora”. Ewangelia głoszona przez Jezusa Chrystusa zwiastowała zwycięstwo nad złem fizycznym, psychicznym i duchowym. Dobra Nowina przywracała ludziom psychiczną równowagę i wyprowadziła ich z mocy zła, zaś zapowiedź zbawienia w nauczaniu Jezusa stała się nagłym doświadczeniem fizycznego zdrowia, psychologicznej wolności oraz duchowego wyzwolenia ${ }^{43}$.

Kluczową sprawą edukacji religijnej ukierunkowanej chrystocentrycznie jest odkrycie na nowo faktu zmartwychwstania Jezusa Chrystusa. Zmartwychwstanie Jezusa stanowi potwierdzenie tego, że zbawienie człowieka nie jest utopia, ale rzeczywistością ukazującą zwycięstwo nad złem i każdą ludzką ułomnością. Zmartwychwstanie jest zapowiedzią naszego zmartwychwstania i ostatecznym motywem dla chrześcijan do ,zaangażowania się w świecie oraz w nadziei pokładanej w przyszłości"44. Duchowość wielkanocna otwiera dla wszystkich perspektywy lepszego życia: dla niechrześcijan ma wartość urzekającego entuzjazmu; dla chrześcijan odkrywa cel ostatecznej wędrówki; w młodych, którym zostaje powierzony ster historii, rozbudza ufność i nadzieję ${ }^{45}$.

Następne zadanie proponowane przez Tertio millennio adveniente polega na określeniu tzw. eklezjalności (odzyskanie świadomości eklezjalnej). „Bez Kościoła nie istniejemy, ponieważ jest niemożliwe wyobrażenie sobie chrześcijanina poza Ciałem Chrystusa"46. Chrześcijańskie życie osobiste posiada istotny aspekt wspólnotowy. Każde spotkanie z Chrystusem w Kościele posiada wartość spotkania sakramentalnego, gdzie następuje udzielenie łaski i odkupienia ${ }^{47}$.

Ważnym postulatem Listu Apostolskiego jest kwestia nawrócenia. Tertio millennio adveniente za Lumen gentium podaje, że „Kościół obejmujący w swoim łonie grzeszników, świętych i zarazem potrzebujących oczyszczenia, podejmuje ustawicznie pokutę i odnowienie swoje. [...] Nie może on [Kościół - D. W.] przekroczyć progu nowego tysiąclecia, nie przynaglając swoich synów do oczyszcze-

${ }^{41}$ Tertio millennio adveniente, s. $2-5$.

${ }^{42}$ R. Fisichella, dz. cyt., s. 171-172.

${ }^{43}$ Jezus Chrystus, jedyny Zbawiciel świata, wczoraj, dziś i na wieki, Oficjalny dokument Papieskiego Komitetu Obchodów Wielkiego Jubileuszu Roku 2000, Katowice 1996, s. 83.

${ }^{44}$ Tamże, s. 116.

${ }^{45}$ Tamże, s. 139.

${ }^{46}$ R. Fisichella, dz. cyt., s. 173-174.

${ }^{47}$ Jezus Chrystus, jedyny Zbawiciel świata, s. 83. 
nia się przez pokutę z błędów, niewierności, niekonsekwencji i zaniedbań" ${ }^{\text {48 }}$. By móc zrozumieć nowość Dobrej Nowiny, którą Jezus Chrystus przynosi na ziemię, konieczna jest zmiana stylu życia ${ }^{49}$.

Jednym z najbardziej niepokojących aspektów współczesnego świata, który stanowi również wezwanie dla edukacji religijnej w przyszłości, jest brak nadziei. Obowiązkiem chrześcijan żyjących współcześnie jest odkrywanie znaków nadziei. Jan Paweł II zauważa:

Konieczne jest także podkreślenie i głębsze rozeznanie znaków nadziei, dostrzegalnych u schyłku obecnego stulecia mimo cieni, które często je zakrywają przed naszym wzrokiem. W dziedzinie życia społecznego są to na przykład osiagnięcia nauki, techniki, a nade wszystko medycyny w służbie życia ludzkiego, żywsze poczucie odpowiedzialności za środowisko naturalne, dążenie do przywrócenia pokoju i sprawiedliwości, gdziekolwiek zostały naruszone, wola pojednania i solidarnego współżycia między różnymi narodami, zwłaszcza w kontekście złożonych relacji między Północą i Południem świata. W życiu Kościoła zaś tymi znakami są: uważniejsze nasłuchiwanie głosu Ducha Świętego, czego wyrazem jest przyjęcie charyzmatów i promocja laikatu, intensywna działalność na rzecz jedności wszystkich chrześcijan, znaczenie przypisywane dialogowi z religiami i ze współczesną kulturą ${ }^{50}$.

Chrześcijanie są wezwani nie tylko do stawiania znaków nadziei, ale również do nadania wartości tym znakom. Ostateczną zaś „zasadą nadziei” dla chrześcijan jest Jezus Chrystus i Jego orędzie zbawienia ${ }^{51}$.

Wskazania Tertio millennio adveniente w perspektywie obchodów trzeciego milenium chrześcijaństwa stanowily wielkie wezwanie dla wierzących, celem odnowienia własnej przynależności do Jezusa Chrystusa. Wezwanie Jana Pawła II do „wiary i świadectwa” prowadzi, zdaniem C. Ruiniego, „do wyostrzenia centralności kwestii prawdy: ponieważ wiara jest taką, jedynie jako akt wolny i rozumny, w którym osoba uznaje, poprzez impuls łaski, że Jezus Chrystus jest prawdą, zbawieniem historii i Jemu powierza się dobrowolnie w całości, a świadectwo (aż do swej najwyższej formy, jaką jest męczeństwo) wypływa jedynie $\mathrm{z}$ tej świadomości prawdy i jest skuteczne, jeśli jest skierowane na przekazanie wiary, której jest nosicielką" ${ }^{52}$.

\footnotetext{
${ }^{48}$ Tertio millennio adveniente, s. 33.

${ }^{49}$ R. Fisichella, dz. cyt., s. 174-175.

${ }^{50}$ Tertio millennio adveniente, s. 46.

${ }^{51}$ Jezus Chrystus, jedyny Zbawiciel świata, s. 186.

${ }^{52}$ Tamże, s. 282.
} 


\section{Zakończenie}

Analiza dokumentów Kościoła z przełomu wieków, pozwala dostrzec potrzebę ewangelizacyjnego ustawienia pedagogiki chrześcijańskiej wobec ciagle zmieniających się uwarunkowań społeczno-kulturowych, w których żyją adresaci orędzia zbawienia. $Z$ jednej strony, przemiany zachodzące w świecie i powstające zagrożenia stawiają określone zadania tej edukacji, a z drugiej strony, ona sama powinna na te przemiany wpływać. Edukacja religijna chcąc być związana z życiem, musi być obecna w świecie i właściwie odczytywać kierunki przemian, które stanowią dla niej konkretne wezwania ${ }^{53}$.

W Polsce ponadto nowa sytuacja szkolnej edukacji religijnej zrodziła dodatkowe wyzwania w perspektywie nowego tysiąclecia. Słusznie zwraca się tu uwagę, że w takiej sytuacji edukacja religijna nie może być jedynie przekazem wiedzy religijnej, ale musi doprowadzić uczniów do rozwoju wiary i postawy świadectwa. Ważnym zadaniem polskiej religijnej edukacji szkolnej jest także ukazywanie więzi między chrześcijaństwem i kulturą polskąa ${ }^{54}$.

Bogate i precyzyjne wytyczne, które formułuje Jan Paweł II w Tertio millennio adveniente, wyrastają z głębokiej analizy potrzeb Kościoła i świata. Przyjrzenie się procesowi rozwoju i określenie specyficznych wartości pedagogiki chrześcijańskiej pozwoli nam na wyciągnięcie wniosków co do jej kształtu w perspektywie trzeciego tysiąclecia. Wyraźnie widać, iż aby sprostać wyzwaniom przyszłości, winna ona być stale obecna w zmieniającym się środowisku społeczno-kulturowym uczniów. Ukształtowany współcześnie pluralizm społeczno-kulturowy oraz związane z nim przemiany religijno-moralne stanowią ważny punkt odniesienia dla jej roli w przyszłości. Edukacja religijna uczy odporności na zagrożenia, jakie niesie ze sobą świat, kształtując w uczniach postawę dojrzałej wiary i świadectwa. Wobec powyższych warunków ich życia i zadań, jakie sobie sama stawia, właściwe jest też jej ewangelizacyjne ustawienie.

Współcześnie dla młodego człowieka chrześcijaństwo i jego pedagogika stanowią jedynie jedno $\mathrm{z}$ wielu źródeł informacji o wychowaniu, a w szczególności o tradycji. Jednakże sama tylko siła tradycji to zbyt mało wobec olbrzymiej mnogości idei, koncepcji filozoficznych i religijnych, sprawiającej wrażenie, iż wszystkie prezentowane w ich ramach wartości są poniekąd równoważne. Również narzucany przez kulturę masową styl życia i bycia wysoce utrudnia proces wychowawczy, oparty na przekazywaniu młodzieży chrześcijańskiego systemu wartości, niezgodnego - jak może się wydawać - z tym, co lansują media.

${ }^{53}$ M. Majewski, Tożsamość katechezy integralnej, Kraków 1995, s. 31.

${ }^{54}$ Tamże s. 42; J. Krakowski, Stanowisko Kościoła katolickiego w sprawie nauczania religii w szkołach, w: J. Krakowski (red.), Nauczanie religii, Lublin 1991, s. 20; por. T. Miłek, dz. cyt., s. $76-80$. 
Trudnością zasadniczą w całym procesie edukacji, niezależną od praktycznego kształtu pedagogiki chrześcijańskiej, z którą jednak musi się ona liczyć, jest - z jednej strony - nadmierny niejednokrotnie krytycyzm młodzieży, bezlitosne testowanie i podważanie wszelkich koncepcji wychowania, z drugiej - brak u młodych ludzi potrzeby intelektualnego zgłębiania chrześcijaństwa, a nawet brak zainteresowania $\mathrm{z}$ ich strony istotnymi problemami otaczającej go rzeczywistość. Ponadto trudnością obiektywną jest też zniekształcenie współczesnej kultury, polegające na jej uprzedmiotowieniu, kierowaniu ofert do „,przedmiotów nabywczych" zamiast do osób. Tego rodzaju dylematy i próby ich rozwiązań muszą stać w centrum uwagi pedagogiki chrześcijańskiej zorientowanej praktycznie.

Ludzkość początku XXI wieku pragnie i musi rozstrzygnać, kim ma być człowiek obecnego stulecia. Dylematami o podstawowym znaczeniu są wobec tego m.in. pytania:

- czy młodzież XXI wieku powinna być wychowywana przede wszystkim na obywateli świata, czy raczej na członków określonej kultury, grupy etnicznej, narodu?;

- czy należy rozwijać wrażliwość na drugiego człowieka, solidarność międzyludzką, empatię, czy raczej uodparniać na zalew informacji o cierpieniach innych ludzi, uczyć akceptowania bezradności wobec ich losu?;

- czy należy kształcić człowieka totalnie wolnego, rezygnując z trudniejszych wymagań, czy przeciwnie - stawiać trudne zadania i wyraźnie określać normy działania etycznego?

$\mathrm{Na}$ te i podobne pytania próbuje obecnie udzielić odpowiedzi pedagogika chrześcijańska. Przyjmowanie w wychowaniu koncepcji człowieka jako osoby we wszystkich jej wymiarach pozwala w dużym stopniu na uniknięcie cywilizacyjnych niebezpieczeństw. Należy przypuszczać, że w XXI wieku zwycięży taka koncepcja wychowania, która pozwoli człowiekowi na uwolnienie go od wszechobecnego poczucia alienacji, która nie zadowoli się pozorem i namiastką wolności, ale udzieli mu rzetelnie umotywowanych wskazań, ukazując blaski i cienie dokonywanych w wolny i świadomy sposób wyborów. W odczuciu piszącej te słowa taką koncepcję wychowania proponuje właśnie pedagogika chrześcijańska.

\section{The Christian education in the light of the literature and the documents of the Church at the threshold of third millennium - perspectives of the development} (Summary)

Nowadays the role of Christian pedagogy in the formation of the man's identity as an individual in the community of social life is not the subject of wider discussions. It seems to be indispensable not only in regard of the tradition and the past, but mostly in 
regard of the present and the future. The man it in day of informative technology, active civilization changes, which are always followed by the necessity of solving the problems of existential nature, needs constant and solid references and permanent values which will enable his full personal development. Just there, Christian conception of education, in centre of which stand man as a person (conscious and free subject) together with his integral development, can play the main role.

In the light of the above, the intention of this article is to show the chances possibilities of Christian education against a background of literature and the documents of the Church at the threshold third millennium. However, the main aim of it is to answer the question why it is worth and even necessary to draw an inspiration in the Christian education. 